\title{
Write Like a Visual Artist: Tracing artists' work in Canada's textually mediated art world
}

\author{
JANNA KLOSTERMANN
}

\begin{abstract}
This study examines the social organisation of Canada's art world from the standpoint of practising visual artists. Bringing together theories of literacy and institutional ethnography, the article investigates the literacy practices of visual artists, making visible how artists use written texts to participate in public galleries and in the art world. Drawing on extended ethnographic research, including interviews, observational field notes and textual analyses, the study sheds light on the ways visual artists enact particular texts, enact organisational processes, and enact the social and institutional worlds they are a part of. Through the lens of visual artists, the study locates two particular texts - the artist statement and the bio statement - in the extended social and institutional relations of the art world.
\end{abstract}

\section{Introduction}

We [visual artists] are knowledgeable about the materials, but just because we know how to mix oil paint doesn't mean anything. ... We're not necessarily solving a problem; we're engaged in communication and in translation through other material means. - Sharon Katz

They [art school professors] do give you a little practical material experience, which is awesome, but really what they're doing is teaching you to be a functioning artist with the written component and the verbal component and the connections with various people in order to further your career. - Beth

McCubbin

Taken from interviews with practising visual artists, the above excerpts highlight artists' experiences using language to participate in

(C) 2016 Janna Klostermann. This is an Open Access article distributed under the terms of the

Creative Commons Attribution 4.0 Unported (CC BY 4.0) License

(https://creativecommons.org/licenses/by/4.0/), allowing third parties to copy and redistribute the

material in any medium or format and to remix, transform, and build upon the material for any

purpose, even commercially, provided the original work is properly cited and states its license.

Citation: Literacy and Numeracy Studies 2016, 24(2):5060

http://dx.doi.org/10.5130/Ins.v24i2.5060

LITERACY AND NUMERACY STUDIES VOL 24 NO 22016 
Canada's art world. Visual artist Sharon Katz stresses the importance of engaging in 'communication and in translation', while visual artist Beth McCubbin underscores the importance of having the 'written component and the verbal component'. They make clear that, in Canada's art world, being 'knowledgeable about the materials' or having 'practical material experience' is only one aspect of their work. They talk about writing artist statements, biographical statements (known as bio statements), curriculum vitaes (known as $\mathrm{CVs}$ ), grant applications and gallery applications. They talk about how language plays a key part in their work as visual artists, and they describe Canada's art world as a text-heavy environment. This article returns, in the findings, to look again at these experiences. To begin, let us trace research in literacy studies and institutional ethnography.

Past scholarship has taken a social approach to the literacy practices of professionals (Barton and Papen 2010, Jackson and Slade 2008, Papen and Tusting 2008), making visible how producing, using and interacting with texts are essential workplace activities.

Professionals use texts to accomplish organisational processes and to accomplish their organisational worlds. This text-based work is inherently dialogical. As Hull (1995) puts it, to be literate is to know 'when to speak, when to be quiet, when to write, when to reveal what was written, and when and whether and how to respond to texts already written'. Professionals are tasked with producing particular texts, producing knowledge (Hyland 2004, Tardy 2005), and producing a place for themselves in the world (Dyson 2008). Textbased literacy work is critical as contemporary work is becoming increasingly textualised (Barton and Papen 2010, Griffith and Smith 2014).

Attending to texts, recent institutional ethnographies have examined critically how work is coordinated in organisations, and how much of that work is coordinated through the medium of texts. By and large, these studies have investigated work in the public sector; including in health (Rankin and Campbell 2006, Rankin and Tate 2014, Sinding 2014), education (Darville 2014, Kerr 2014, McCoy 1998, Wright 2014), social services (Janz 2014, McCoy 2014, Nichols 2014), and international development (Campbell 2014, Eastwood 2005). Starting in particular places where people work and do things together, these studies have kept people and texts in view, while investigating coordinated work that is (sometimes) out of view. These studies have traced how textual technologies (and managerial re-organising initiatives) translate the actualities of people's real work 
into standardised, measurable and managerial forms (see Griffith and Smith 2014). In examining visual artists' work, it wasn't initially obvious how the art world fits in with studies about medical charts, standardised reports, educational policies and behavioural tracking charts - nor was it obvious how artists' experiences are connected to other institutional practices and relations. That said, Beth and Sharon indeed point to a text-based terrain of inquiry. Similar to past research that has examined the artist statement as a work of art itself (Nash and Garrett-Pettz 2007), Beth and Sharon underscore the social and institutional work that artist statements and bio statements enact. They hint that their work is coordinated through the medium of texts; permeating with and put together by extended, coordinated practices and relations.

Responding to their experiences, this research extends scholarship in literacy studies and in institutional ethnography by examining visual artists' coordinated, text-based work. The research investigates visual artists' literacy practices and the ways those practices mediate relations in public galleries and in Canada's art world. The following questions guide the inquiry: (1) How do visual artists use written texts to participate in public galleries and in Canada's art world? (2) What social and institutional purposes do written texts - artist statements and bio statements - serve?

This article takes up these strands of inquiry through institutional ethnographic research involving qualitative interviews, observational field notes and textual analyses. The aim is to make visible how visual artists participate discursively in public galleries and in the art world. The study makes visible that navigating the art world doesn't happen in an abstract way, but through particular written utterances. Artists display conceptual seriousness in their artist statements, and professional competence in their bio statements. They use writing to enact organisational processes, funneling their work out of their studios and into public galleries. They use writing to participate in, take part in shaping, play with and poke fun at the discursive conventions of the art world; an art world that is conceptual and reputable, and in which an experiential practice is harder to maintain. This research situates two particular texts - the artist statement and the bio statement - in the extended social and institutional relations of the art world. 


\section{Theoretical framework}

This study is motivated by past research that has taken a social approach to literacy practices (Papen and Tusting 2008), looking beyond particular texts to examine the practices involved in producing and using them. To investigate the ways visual artists use texts to participate in the art world, this study draws on social theories of literacy (Barton and Hamilton 1998) and on institutional ethnography (Smith 2005). Theories of literacy allow the researcher to attend to particular texts and to particular practices and relations, while taking an institutional ethnographic approach allows the researcher to explicate how those literacy practices and relations, which centrally involve texts, are situated within extended social and institutional relations. This article narrows in on particular texts and particular practices and relations, while tracing out the art world.

Taking a social view of literacy, this paper attends to visual artists' literacy practices and literacy relations. The study conceptualises literacy not as decontextualised skills (such as an individual's ability to read or write), but as practices and relations involving texts (Darville 2001). The study conceptualises literacy practices as social, purposeful, and historically situated (Barton and Hamilton 1998). Literacy practices include ways of engaging with particular texts - reading, writing and interpreting - and 'ways of thinking about and doing reading and writing in cultural contexts' (Street 2003:79). Literacy practices can be experiential, concerned with telling individual experience, or organisational/institutional, concerned with the world through concepts and categories (Darville 1995, 2009). Literacy practices are bound up with literacy relations; relations that involve knowing 'when to speak, when to be quiet, when to write, when to reveal what was written, and when and whether and how to respond to texts already written' (Hull 1995:19). Further, literacy practices are patterned by power relationships, social structures and institutions (Papen and Tusting 2008). Literacy is not about a final product or final display of knowledge, but about getting things done (Paré 2009) and meeting social goals (Artemeva and Freedman 2006). From this perspective, textual analysis involves explicating how particular texts are in relation to particular others and particular social and institutional worlds.

Focusing on the particular, the aim of institutional ethnography is to trace how practices and relations are coordinated socially and institutionally (Smith 2005). An institutional ethnographer begins by 
working with people - in this case visual artists - to understand their situated experiences and knowledges. From there, the ethnographer traces how people's everyday experiences are coordinated with the experiences of others, with institutional texts, and with social and institutional relations that extend beyond them. Institutional ethnography explores how 'the very organization of the everyday is permeated with connections that extend beyond it' (Smith 2005:40). In institutional ethnography, the notion of social relations 'orients the researcher to viewing people's doings in particular local settings as articulated sequences of action that hook them up to what others are or have been doing elsewhere and elsewhen' (Smith 2005:228). Institutional ethnography provides a framework for attending to the ways people are in relation with near and far flung others, and to the ways people shape and are shaped by (extra-local, extended) social and institutional relations.

Interwoven, the two frameworks allow the researcher to explore visual artists' particular literacy practices and relations, while exploring critically how those practices and relations articulate to, and are shaped by, the extended social and institutional relations of Canada's art world. This study uses the two frameworks to shed light on how visual artists use literacy to position themselves in the art world, and to 'make visible to each other what counts as appropriate discursive and literate practices' (Castanheira, Crawford, Dixon and Green 2000).

\section{Data and methods}

The empirical material for this article is drawn from a larger ethnographic study. As a part of the project, the researcher interviewed people situated differently in Canada's art world. The researcher learned more about artists' work (and about the workings of the art world) through 20 open-ended interviews with 16 participants, including practising visual artists, public gallery curators, art critics and art professors. The researcher also drew on observational field notes (from visits to studios and public galleries), and on textual analyses (of artist statements, bio statements and other public/promotional materials). This paper focuses chiefly on interviews with eight participants (see Table 1) and on textual analyses of artist statements and bio statements. The textual analysis involved explicating particular texts for traces of social organisation for how they helped people to get things done (Paré 2009) and meet social goals (Artemeva and Freedman 2006) - not for traces of 
decontextualised skills, learnt phrases or final displays of knowledge. The research was approved by Carleton University's Research Ethics Board. As per best practices, participants received information about the purpose of the study prior to the interviews. This information included both formal invitation letters and consent forms (that explained their options for remaining anonymous or being identified). All participants included opted both verbally and in writing to be identified by their real names, and to have their responses and data attributed to them. Their work and their words are attributed to them accordingly. Table 1 includes information about participants' cities and work experiences.

Table 1 Study participants

\begin{tabular}{|c|c|c|}
\hline Name & City & Experience \\
\hline $\begin{array}{l}\text { Heather } \\
\text { Anderson }\end{array}$ & $\begin{array}{l}\text { Ottawa, } \\
\text { ON }\end{array}$ & $\begin{array}{l}\text { A curator at the Carleton University Art } \\
\text { Gallery (Ottawa, ON), a public gallery. }\end{array}$ \\
\hline $\begin{array}{l}\text { Sky } \\
\text { Goodden }\end{array}$ & $\begin{array}{l}\text { Toronto, } \\
\text { ON }\end{array}$ & $\begin{array}{l}\text { An art critic and founding editor of } \\
M O M U S \text {, an international art publication. }\end{array}$ \\
\hline $\begin{array}{l}\text { Marika } \\
\text { Jemma }\end{array}$ & $\begin{array}{l}\text { Ottawa, } \\
\text { ON }\end{array}$ & $\begin{array}{l}\text { A visual artist for more than } 20 \text { years. She } \\
\text { works primarily in the mediums of } \\
\text { sculptural installation and video. }\end{array}$ \\
\hline $\begin{array}{l}\text { Sharon } \\
\text { Katz }\end{array}$ & $\begin{array}{l}\text { Ottawa, } \\
\text { ON }\end{array}$ & $\begin{array}{l}\text { A visual artist since } 1983 \text {. She works in } \\
\text { the mediums of drawing and } \\
\text { animation/video. }\end{array}$ \\
\hline $\begin{array}{l}\text { Fynn } \\
\text { Leitch }\end{array}$ & $\begin{array}{l}\text { Peterborou } \\
\text { gh, ON }\end{array}$ & $\begin{array}{l}\text { A curator at the Art Gallery of } \\
\text { Peterborough }(\mathrm{ON}) \text {, a public gallery. }\end{array}$ \\
\hline $\begin{array}{l}\text { Beth } \\
\text { McCubbi } \\
\text { n }\end{array}$ & $\begin{array}{l}\text { Gatineau, } \\
\text { GC }\end{array}$ & $\begin{array}{l}\text { A visual artist and conservator, who has } \\
\text { worked in the arts for } 25 \text { years. She works } \\
\text { primarily with clay, concrete and other } \\
\text { mixed materials. }\end{array}$ \\
\hline $\begin{array}{l}\text { Mary } \\
\text { Porter }\end{array}$ & $\begin{array}{l}\text { Toronto, } \\
\text { ON }\end{array}$ & $\begin{array}{l}\text { A visual artist and an instructor at OCAD } \\
\text { University. She works in the mediums of } \\
\text { painting, drawing and photo-based stop- } \\
\text { motion animation. }\end{array}$ \\
\hline Jinny Yu & $\begin{array}{l}\text { Ottawa, } \\
\text { ON }\end{array}$ & $\begin{array}{l}\text { A visual artist and a professor at the } \\
\text { University of Ottawa, who has been } \\
\text { showing professionally for over } 20 \text { years. } \\
\text { She works primarily in experimental } \\
\text { painting. }\end{array}$ \\
\hline
\end{tabular}




\section{Findings}

The discussion above explored research on literacy practices and relations, and on the ways particular practices mediate relations in contemporary work worlds. What follows is the application of that discussion to visual artists' work. We examine artists' coordinated work to enact the art world, to enact public gallery processes, and to enact particular texts. The aim is to examine how visual artists use language to suture themselves into the social and institutional relations of the art world. Section one on 'enacting the art world' starts by giving a brief overview of artists' coordinated work in the art world. From there, section two on 'enacting public gallery processes' zooms in on artists' work to participate in public galleries, exploring how their work centrally involves language. Zooming in further, section three on 'enacting particular texts' explores artists' work to produce two key institutional texts - artist statements and bio statements. Exploring visual artists' particular literacy practices shines light on the ways professionals use language to enact the social and institutional worlds they are a part of.

\section{Enacting the art world}

While there are, of course, countless ways of entering into the art world, this investigation started with the researcher interviewing practising visual artists about their work and about how written and spoken language is a part of it. Their interviews made visible how the art world is a domain shaped by people interacting with texts and participating in ordinary, everyday practices and relations. The art world - the terrain where art is produced materially/discursively involves an array of connections, discourses, practices and relations. It is coordinated through the ordinary work of various people working across sites. To give an overview, the visual artists interviewed as a part of this study described doing a variety of work as a part of Canada's art world. More particularly, they described working to make art, to sustain their practice and to participate in the art world. When it comes to making art, they described producing art objects, developing their practice, maintaining their studios, and working with ideas and/or intuition. When it comes to participating in the art world, they described producing various written texts, applying for/securing opportunities, selling work, and both following and taking part in the art scene. When it comes to sustaining their practice, they described having material resources, including time, space and money. Of 
course what visual artists know and say about their work conveys what they do - their material practices and their practical engagement in the social relations of the art world. And, this practical engagement centrally involves language. Just as visual artists talked about the importance of text-based work, they also stressed the importance of showing in public galleries.

\section{Enacting public gallery processes}

For visual artists, public art galleries are essential. Ottawa artist Jinny $\mathrm{Yu}$ said, public galleries are 'recognised by my peers as being a legitimate exhibition venue'. As she put it, 'commercial galleries want to have work that is sellable whereas public art galleries' main mandate is to show work that is important'. Showing in a public gallery is not only a way of participating in the art world, it is also an endorsement from the art community, a way of making money, and a way of showing markers of being a professional artist. Showing in a public gallery is an achievement that appears on artists' CVs, and occasionally comes with the opportunity to have work reviewed. Artists typically use language to get in (e.g., exhibition proposals), there is language involved in the exhibition itself (e.g., artist talks, writing on the wall), and there is language to follow as artists' work is sometimes taken up, written about or talked about afterwards. Public galleries are a hub in the Canadian art world where art and language conjoin, commingle and sometimes collide.

Artists approach public galleries in different ways. For example, Mary Porter mentioned it is essential for an artist to find 'ways to articulate projects and the conceptual underpinnings of those projects'. Sharon Katz described ways that communicating about art is sometimes collaborative in the gallery sphere, while Beth McCubbin somewhat distanced herself from the process. While she referred to this collaboration as 'kind of what happens', she said, 'I don't like that stuff. Unfortunately, the essence of me is about none of that. [I'm] sort of about objects for what they are or people for what they are not about having to prove to somebody that you are something'. Irrespective of artists' attitudes to their work in public galleries, it is clear that communicating through written and spoken discourse is crucial to participating in public gallery processes. As a part of their work in public galleries, artists connect formally and informally, attending exhibitions and artist talks, introducing themselves, applying for exhibitions, hosting studio visits, planning exhibitions, installing shows, and scheduling events. They also 
participate in public galleries by interacting with and producing particular texts.

\section{Enacting particular texts}

When applying formally to a public art gallery, artists typically send in exhibition proposals, which include digitised reproductions of their work and written texts (e.g., artist statements, bio statements, $\mathrm{CVs}$ ). While artists are free to interpret proposal requirements broadly and to write as they see fit, there are conventional ways for writing both artist statements and bio statements. Artists do not write from scratch; they often refer to the work of others to get a sense of how to write their own. They place themselves, their art work and their artist statements and bio statements in conversation with others. As the sub-sections below make visible, the artist statement is typically where artists display their conceptual seriousness, while the bio statement is where artists display their professional standing.

Artist statements. Artists are typically required to include artist statements in their exhibition proposals. In speaking about the social purposes of the artist statement, Sky Gooden, an art critic who occasionally leads writing workshops for artists, described them as typically written by artists in order to seek out financial patronage or support for your exhibition practice or [artist] residences'. She mentioned the audience is typically 'granting bodies, exhibitions, artist residencies - from time to time although very rarely collectors'. She said, 'if an artist is applying to a commercial gallery or artist-run gallery for the first time seeking exhibition or representation, that would be a viewing audience as well'. Quoting Sky again:

By and large, it is an internal document. I mean, I'm being somewhat optimistic here, because this is how I would like to see it be used more than anything. In the top sort of registers of the art world, where people are working most professionally, it's really not meant for public consumption. It's meant to inform those who will go on to curate and write about the text at a more-polished and removed level, right? It's meant to give small cues or work as small-change currency, aligning a professional to the artist's intent. But of course the intent is not the only important factor in knowing the artist's work. Largely, in fact, I think it's secondary to an experienced eyes' and minds' reaction and response and positioning of that work. 
So at times, the artist statement isn't meant for the viewing public, but to inform the polished and removed writing of art professionals working internally and professionally. The artist statement 'provide[s] us with a context for viewing', 'both directs the viewer's gaze and indirectly announces or affirms the artist's rite of passage' (Garrett-Petts and Nash 2009). While most galleries don't specify what should or shouldn't be included in the artist statement, they tend to take on standardised forms. Typically, the artist statement is a space for artists to demonstrate their conceptual seriousness, and to make clear connections between work and words.

In reading artists' particular written utterances, we can learn about the art world they are a part of. With a view to considering how artists use written utterances take part in the institutional art world, let us attend to the artist statements of Mary Porter and Beth McCubbin. Mary Porter's (n.d.) artist statement reads as follows:

The longstanding interests that have shaped my art practice have been an inquiry into the built environment and landscape; an interest in utopian and dystopian imagery and narratives; a fascination with the idea of the sublime, that which we can imagine but never fully represent or understand; and how the history of painting is tied up in all these things.

The impetus for my practice has always come out of looking at the built environment to glean some sense of the culture that created it. My understanding of the landscape is formed from my daily experience, from memory, and from the spaces and places that exist in our collective imagination through popular culture. Like the cultural geographer Denis Cosgrove, I believe that "landscape is not merely the world we see, it is a construction, a composition of that world. Landscape is a way of seeing the world."

Beth McCubbin's (n.d.) artist statement reads as follows: I build works of art primarily from clay and from concrete, both alone and in combination with other mixed materials. I create single works or site specific installations comprised of multiple pieces. My installations often require the use of different materials in order to convey a particular meaning, and I very much enjoy the challenge of this.

Presently my sculptures are concerned with expressing figurative movements. They are carefully crafted to direct the viewer to their forms in order to find meaning. My desire is to create sculptures that not only express a recognizable action, but also instil a particular feeling or thought. 
Part of my artistic purpose is to produce works made from environmentally sound materials, recycled or extracted without great impact upon the earth, and using materials that are common, familiar and widely available. It is very important to me that art be approachable and accessible to all people and I feel that perhaps by making it with recognizable materials I am able to assist in this effort.

Both artist statements do conceptual work; both apparently address the expectation to integrate art and language and to convey a concept. There isn't one section devoted to the art and one section devoted to the ideas. Instead, the artist statements integrate art and ideas, sharing how the work embodies a particular concept or connects to a particular idea. That said, while both artist statements talk about the work conveying a concept, they don't do it identically. Mary positions her work as a conceptually ordained, scholarly production. Much like an academic researcher, Mary refers to her art as 'an inquiry into the built environment', discusses the 'impetus for [her] practice', talks about the 'interests that have shaped [her] practice', and closes with a quotation from a cultural geographer. The way that Mary describes her practice connects well with the way public gallery curator Fynn Leitch described looking for work that is 'intentional'. Speaking to Fynn and to the conceptual art world, Mary makes explicit that her art is a purposeful inquiry with a scholarly impetus. She brackets her personal decision making process. While Beth's artist statement does have traces of the conceptual discourse, she also includes features that are part of her own experience. She doesn't remove herself from the write up. For example, she highlights the actual process of making the art. She also emphasises her own personal decision making process, saying, 'I feel that' and 'It is very important to me'. She connects her work to herself; to her own intentions and purpose. When asked about writing in the art world, Beth shared that, 'explaining who you are and why you're creating the works... isn't normally done. ... It's almost too female of a way to do things. ... Male [writing] is not really as much like that. Their purpose is more separated. This is a commentary on the way that it is'. Beth is well aware of the standardised ways of writing (yourself out of) artist statements. Her choice to include her personal decisionmaking process was very much an effort to brush against the system and to resist the institutional pressures to provide an objective commentary on the so-called ' way that it is'. 
In his work on literacy, Darville $(1995,2009)$ draws a distinction between experiential literacy that is concerned with telling individual experience, and organisational or institutional literacy that organises the world through concepts and categories. We can see experiential literacy practices used in the way that Beth describes her own individual preferences, and organisational literacy practices in the way that Mary conceptualises her work. Interestingly, however, for an artist's work to be funnelled out of her studio and into the art world, it needs to eventually take on an organisational form in exhibition promotional materials. It needs to enact organisational processes. It needs to do social and institutional work to hook up with public gallery processes. For example, Sky Goodden pointed out, artwork eventually needs to be written about in a more polished and removed way by art professionals. Similarly, Heather Anderson, a public gallery curator, remarked, 'Writing is valuable to an organisation, because it means that their exhibition does have a life beyond the space of the presentation'. Writing connects the artwork beyond the particular space, hooking it into other organisational processes. For artists, the artist statement is a first move in creating an organisational account of their work, entering into the institutional art world, and getting their work 'validated by other professionals; other people who are engaged in the conversation' (as Mary Porter put it).

Bio statements. Similar to the artist statement examined above, artists are sometimes required to include bio statements in their exhibition proposals. This written document is produced by artists when they are applying for funding, applying to galleries and applying for residencies. While some opportunities ask for a CV (in lieu of the bio statement), bio statements are often included in public gallery texts, including brochures, websites and catalogues. Some artists also include them on their own personal websites. While artists are, again, welcome to write as they see fit, bio statements are conventionally a space for artists to demonstrate their professional standing, and their certification/recognition by universities, art galleries, funding bodies and publications. With a view to considering how artists' written utterances operate in the institutional art world, let us attend to the bio statements of Jinny Yu and Marika Jemma. Jinny Yu's ('General Hardware,' n.d.) bio statement reads as follows:

Born in Korea and based in Canada, Jinny Yu has shown widely, including exhibitions at the ISCP Gallery (Brooklyn), Pulse New York (NY), Scope New York (NY), Bevilacqua La Masa Foundation (Venice), the Kyoto Municipal Museum of 
Art (Kyoto), the Conduit Street Gallery, Sotheby's (London, UK), Carleton University Art Gallery (Ottawa), the Taehwa Eco Art Festival (Ulsan City, Republic of Korea), the Confederation Centre Art Gallery (Charlottetown), and McMaster Museum of Art (Hamilton). Yu, who is Associate Professor of Painting at the University of Ottawa, was awarded Laura Ciruls Painting Award from Ontario Arts Foundation in 2012 and was a finalist for the Pulse Prize New York 2011. In 2012 Jinny's work was featured in the main space at The Canadian Painting Survey exhibition 60P. She has received grants from the Canada Council for the Arts, Ontario Arts Council, and le Conseil des Arts et des Lettres du Quebec. Jinny Yu has recently returned from her solo exhibitions in Seoul Korea at KunstDoc Art Gallery and Nanji Art Gallery of Seoul Museum of Art. In 2012 Yu's work was included in the ambitious 60 Painters exhibition and catalogue, an overview of contemporary Canadian painting.

Marika Jemma's ('Enriched Bread Artists,' n.d.) bio statement reads as follows:

Born 1963 in West Toronto, enduring a non-descript Catholic childhood and surviving the banality of a whitewashed suburban existence in the pursuit of modest personal debt, Marika left home at 17 to experience the joys of minimum wage, public transportation and a series of rooming houses in various dissociated communities in southern Ontario.

An independent learner, Marika has explored the public libraries of most of the major cities in Canada and on a rainy day in 1982, a greyhound bus deposited her in the city of Vancouver. Due to the works of Jane Rule and Jack Hodgkins, Marika moved to Vancouver Island where she spent the next 11 years pursuing a series of odd-jobs, training as a carpenter and finally graduating from art school in 1991.

Her first vehicle was a 1969 GMC step-side, short box pick up, painted matte black with a cracked windshield. Her first girlfriend drove a motorcycle. Her first solo show was called "Journey To The Temple" at Xchanges Gallery, Victoria, B.C. 1991.

In 1993, Marika drove back across the country in a 1973 Toyota Corolla, dropped the muffler on a raised railway bed in southern Saskatchewan and ran out of gas in Ottawa and has been here ever since.

Marika joined the Enriched Bread Artists in 1998. 
In examining the bio statements of Jinny and Marika above we can learn more about the discursive terrain of the art world that those written utterances are embedded in. Both artists use their statements to position themselves in or in relation to the art world. Jinny positions herself at the centre of the organisational art world, while Marika plants herself on the outskirts. Jinny's bio statement makes her professional standing and recognition discursively explicit. While Jinny's bio statement closes by mentioning the medium she works in, the rest of the bio is devoted to her institutional affiliations. The statement details her numerous gallery showings, her work as a professor, her grants, her awards and her publications. In contrast, Marika's tongue-in-cheek account hardly mentions her institutional affiliations. Instead of an institutional, polished account, she talks about life on the ground. She starts outside of the art world, underscoring minimum wage work, rooming houses, odd-jobs, and even a cracked window in her 1969 GMC step-side. When I asked about writing her bio statement, Marika said:

It's a bit flippant, and it is because I don't have academic credentials that I wish to - that would serve me in terms of people who would be assessing me based on my academic credentials - so assigning credibility or not assigning credibility based on, you know, where I went to school, whatever that means. So what I'm trying to say is that learning happens, and education happens, everywhere all the time. So, whether or not you actually have a degree that you paid for is not necessarily an indicator of how well-educated you are or how intelligent you are or any of those things.

Her 'flippant' bio statement is a way of thumbing her nose at institutional requirements and at the demand to 'have a degree that is paid for'. She goes on to say, 'I think I was a little bit reactive to [mocking] "so and so studied with so and so and the humphhh and did this and that and the other thing"'. As opposed to Jinny's institutional account, offering a cluster of 'recognitions' in awards and gallery showings, Marika offers an experiential, chronological account of her 'haphazard path'. In referring to her own statement as 'flippant' and 'reactive', Marika points to (by poking fun at) standardised ways of using language and of navigating the institutional art world. Again, these texts display the workings of the art world; an art world that is increasingly conceptual and in which an expressivist practice is harder to sustain. 
When asked about whether or not an artist's identity should be communicated in her writing, Sky Gooden pointed out how, in her view, it can be a problem to have parts of a person's biography included in writing about artwork. She said:

Biography plays its part.... I think that can be a problem though. It can make for lazy art. It can make for lazy viewing, and sympathies become manipulated such that we're linking admission of, you know, difference to the production of good work, which is not a given by any stretch of the imagination, so I'm hesitant about it. ... We have to let art exist in a space where the product is not necessarily linked to its author as demonstrative of that author's experience. The work, in essence, should be allowed to sort of be positioned at a remove from that biography and be performative of any number of other truths that that author wanted to pen, so to speak.

Here Sky asserts that including biographical information and admitting difference can make for lazy art, and can interfere with the production, presentation and uptake of good work. For art to be taken seriously, and for an artist to participate in public gallery processes, the work needs to be 'positioned at a remove from [their] biography'. The work needs to enact organisational processes. It needs to do social and institutional work. The juxtaposition with Jinny and Marika's bio statements, then, is between experiential literacy that is 'anchored in lived experience' and an organisational literacy that is 'anchored in organizational or professional processes' (Darville, 1995:250). Offering an organisational account is both a way of conveying professional standing and a way of participating in the art world. To participate in the art world, artists, like other professionals, 'employ textual realities to mediate the details of their daily practice' (de Montigny, 1995:209). Through their writing, artists 'perform discursive work and produce a continuous series of presentations of self which demonstrate the proper professional and organizational motivation' (de Montigny, 1995:216). They show their own institutional standing, while also bolstering the standing of the institutions they are a part of. Their textual practices, along with producing their own legitimacy, produce the legitimacy of the institutions they work in (Rusted, 2006:121).

\section{Using theories of literacy and institutional ethnography}

This study has drawn on theories of literacy and institutional ethnography to investigate the coordinated, text-based work of visual 
artists. The paper examined artists' particular literacy practices and relations, while also exploring critically how those practices and relations articulate to, and are shaped by, particular social and institutional contexts. We started with experience, narrowed in on particular practices and relations, and traced out the regime from there. While this study is a modest effort to trace visual artists' textbased work, it speaks to research in critical literacy studies and institutional ethnography.

Past critical literacy studies have found professionals are tasked with 'composing a text and composing a place for oneself in the world' (Dyson 2008:229). Similarly, this article has explored how using writing can be a way for visual artists to participate in public galleries and in the art world. Similar to other workplace literacy practices, visual artists use written texts to produce themselves as 'disciplined, competitive and self-governing subjects with certain levels of commitment and responsibility' (Thomas-Long 2010:41). Visual artists write, not only to represent themselves and their work, but to navigate the art world. Navigating the art world involves figuring out how others tend to correspond with one another and participating in communities that are shaped by practices and relations of power. And, power, as this paper has explored, is locally achieved and enacted through particular utterances (see Kostouli 2009) and in relation to particular others.

This study also speaks to research in institutional ethnography. Past studies have found that textual technologies translate the actualities of people's work into standardised, measurable and managerial forms (see Griffith and Smith 2014). Past studies have also highlighted how people's actual work is being slotted into, subsumed by, and subjected to extra-local institutional work processes. Like many contemporary organisations, the modern art world is increasingly textually and institutionally coordinated. That said, while the art world is indeed institutional, it is only in part conventionally bureaucratic. It is important to underscore that there isn't some single elite that makes up objectifying categories, and then issues diagnoses or administrative decisions. Working artists are not only subject to judgment with regard to their particular written utterances, they contribute to bringing them about. They respond to and bring about organisational work processes, slotting their work into organisational forms and positioning their work at a remove from their biographies and experiences. They produce artist statements that display conceptual seriousness, and bio statements that display their 
professional standing. They enact the art world through their everyday work - sculpting themselves, sculpting their work/words, and sculpting the social and institutional art world.

\section{Conclusion}

With a view to learning more about the social organisation of Canada's art world, this article traced how visual artists navigate public galleries and navigate the art world. Writing plays an important role in visual artists' navigational work. Through their interaction with and production of particular written texts, artists represent themselves, while navigating particular public gallery processes. Just as people use writing to reinforce and recontextualise links between themselves and particular settings (Tusting 2015:249), visual artists use writing to reinforce and recontextualise links between themselves and the art world. This, again, happens through particular written utterances. Artists display conceptual seriousness in their artist statements, and professional competence in their bio statements. Displaying conceptual seriousness and professional competence, however, are not about stand-alone skills, learnt phrases or final displays of knowledge; they are ways of getting things done, responding to organisational goals, and stitching oneself and one's work into particular social or institutional relations. Through their engagement with written texts, artists work to funnel their work out of their studios and into public galleries. They participate in, take part in shaping, play with and poke fun at the discursive conventions of the art world. That said, while writing can come with many professional advantages and can be a way to enact organisational processes and position oneself in the art world, some of the visual artists interviewed expressed reservations about their ability to position themselves in the art world. These concerns were less about their word choice, about their own professional abilities, or about the quality of their art. Their concerns were less about 'a relatively tangible set of items, rules or formulas (Rose 2012)' and more 'bound up with content, and by extension, with ways of being, that cannot be captured by an isolated set of grammatical rules or structures alone' (Bak and O'Maley 2015:66). Their concerns were about how they could best manifest as thinkers while navigating the art world. And, again, it is important to underscore that the art world often decentres people who do not frame (their) art in institutional terms. Within this increasingly conceptual, reputable and organisational art world, an experiential practice is harder to frame, legitimate or squeeze into 
public galleries and into the art world. By bringing attention to this, and to differences between artists' experiential and organisational literacy practices, this study shines an ethnographic light on artists' work and on Canada's social and institutional art world.

\section{Acknowledgements}

I would like to express my gratitude to Richard Darville and Graham Smart for their invaluable guidance and support with this study.

\section{References}

Artemeva, N and Freedman, A (2006) Rhetorical Genre Studies and Beyond, Inkshed Publications, Winnipeg, MB.

Bak, T and O'Maley, P (2015) Towards professional responsibility for language and literacy: Exploring vocational teachers' emerging language and literacy understandings and identities, Literacy and Numeracy Studies, vol 23, no 1, pp 5072, doi: http://dx.doi.org/10.5130/lns.v23i1.4424

Barton, D and Hamilton, M (1998) Local Literacies: Reading and writing in one community, Routledge, London.

Barton, D and Papen, U, eds (2010) The Anthropology of Writing: Understanding textually mediated worlds, Continuum, London.

Campbell, M (2006) Institutional ethnography and experience as data, in Smith D E, ed, Institutional Ethnography as Practice, Rowman and Littlefield Publishers, New York, pp 91-108.

Castanheira, ML, Crawford, T, Dixon, CN, and Green, JL (2001) Interactional ethnography: An approach to studying the social construction of literate practices, Linguistics and Education, vol 11, no 4, pp 353-400, doi: http://dx.doi.org/10.1016/s0898$\underline{\text { 5898(00)00032-2 }}$

Darville, R (1995) Literacy, experience, power, in Campbell, $\mathrm{M}$ and Manicom A, eds, Knowledge, Experience and Ruling Relations: Studies in social organization of knowledge, University of Toronto Press, Toronto, pp 249-261.

Darville, R (2001) Adult literacy as social relations: A democratic theorizing, 20th Anniversary Proceedings of the Conference of Canadian Association for Studies in Adult Education (CASAE), pp 61-66.

Darville, R (2009) Literacy as practices, teaching as alignment: A message in a bottle, Literacies: Researching Practice, Practising Research, vol 10, pp 14-18. 
de Montigny, G (1995) The power of being professional, in Campbell, $\mathrm{M}$ and Manicom A, eds, Knowledge, Experience and Ruling Relations: Studies in social organization of knowledge, University of Toronto Press, Toronto, pp 209-220.

Dyson, AH (2008) Staying in the (curricular) lines: Practice constraints and possibilities in childhood writing, Written Communication, vol 25, pp 119-157.

Eastwood, L (2005) The Social Organization of Policy: An institutional ethnography of UN forest deliberations, Routledge, New York.

'Enriched Bread Artists' (n.d.) Marika Jemma, Enriched Bread Artists, retrieved 15 Nov 2014 from http://www.enrichedbreadartists.com/members/jemma.htm

Garrett-Petts, WF, and Nash, R (2009) Re-visioning the visual: Making artistic inquiry visible, in Garrett-Petts, WF and Freeman JC, eds, Rhizomes 18, retrieved 1 April 2015 from http://www.Rhizomes.net

'General Hardware' (n.d.) Jinny Yu, General Hardware Contemporary, retrieved 1 April 2015 from http://generalhardware.ca/jinny-yu/

Griffith, AI and Smith, DE (2014) Under New Public Management: Institutional ethnographies of changing front-line work, University of Toronto Press, Toronto.

Hull, G (1995) Controlling literacy: The place of skills in 'high performance' work, Critical Forum 3, vol 2 no 3, pp 3-26.

Hyland, K (2004) Disciplinary Discourses: Social interactions in academic writing, University of Michigan Press, Ann Arbor, MI.

Jackson, N, and Slade, B (2008) 'Hell on my face': The production of workplace illiteracy, in DeVault, M, ed, Embodied Workers in The New Economy, New York University Press, New York, pp 25-40.

Janz, S (2014) For-profit contractors, accreditation, and accountability, in Griffith, AI and Smith, DE, eds, Under New Public Management: Institutional ethnographies of changing front-line work, University of Toronto Press, Toronto, pp 204212.

Kerr, L (2014) E-governance and data-driven accountability: OnSIS in Ontario schools, in Griffith, AI and Smith, DE, eds, Under New Public Management: Institutional ethnographies of 
changing front-line work, University of Toronto Press, Toronto, pp 85-121.

McCoy, L (2014) 'If our statistics are bad we don't get paid':

Outcome measures in the settlement sector, in Griffith, AI and

Smith, DE, eds, Under New Public Management: Institutional ethnographies of changing front-line work, University of Toronto Press, Toronto, pp 234-250.

McCoy, L (1998) Producing 'what the deans know': Cost accounting and the restructuring of postsecondary education, Human Studies, vol 21, pp 395-418.

McCubbin, B (n.d.) About Beth, Beth McCubbin, retrieved 1 April 2015 from https://bethmccubbin.wordpress.com/

Nash, R and Garrett-Petts, WF (2007) Artists' statements and the nature of artistic inquiry, Special Issue of Open Letter, vol 13, no 4.

Nichols, N (2014) Youth Work: An institutional ethnography of youth homelessness, Toronto University Press, Toronto.

Nochlin, L (1971) Why have there been no great women artists?, The Feminism and Visual Culture Reader, pp 229-233.

Papen, U, and Tusting, K (2008) Creativity in everyday literacy practices: The contribution of an ethnographic approach, Literacy and Numeracy Studies, vol 16, no 1, pp 5-25, doi: http://dx.doi.org/10.5130/lns.v16i1.1945

Paré, A. (2009) What we know about writing, and why it matters, Compendium: Writing, teaching, and learning in the university, vo1 2, no 1, pp 1-7.

Porter, M (n.d.) Bio/CV, Mary Porter. Retrieved 1 April 2015: http://www.maryporter.ca/bio.html

Rankin, J and Campbell, M (2006) Managing to Nurse: Inside canada's health care reform, University of Toronto Press, Toronto.

Rankin, J and Tate, B (2014) Digital era governance: Connecting nursing education and the industrial complex of healthcare, in Griffith, AI and Smith, DE, eds, Under New Public Management: Institutional ethnographies of changing frontline work, University of Toronto Press, Toronto, pp 122-147.

Rusted, B (2006) Performing visual discourse: Cowboy art and institutional practice, Text and Performance Quarterly, vol 26, no 2, pp 115-137, doi: http://dx.doi.org/10.1080/10462930500519481 
Sinding, C (2014) Institutional circuits in cancer care, in Griffith, AI and Smith, DE, eds, Under New Public Management:

Institutional ethnographies of changing front-line work, University of Toronto Press, Toronto, pp 273-293.

Smith, DE (1989) Feminist reflections on political economy, Studies in Political Economy, vol 30, pp 37-59.

Smith, DE (2005) Institutional Ethnography: A sociology for people, AltaMira, Lanham, MD.

Street, B (2003) What's 'New' in New Literacy Studies? Critical approaches to literacy in theory and practice, Current Issues in Comparative Education, vol 5, no 2, pp 77-91.

Tardy, C (2005) 'It's like a story': Rhetorical knowledge development in advanced academic literacy, Journal of English for Academic Purposes, vol 4, no 4, pp 325-338.

Tusting, K (2015) 'I am a peacemaker': Writing as a space for recontextualizing children's identity in a Catholic First Communion Preparation Course, Written Communication, vol 32, no 3, 227-253.

Thomas-Long, R (2010) Producing the graduate student: A textual analysis of funding through scholarship application, Atlantis: Critical Studies in Gender, Culture and Social Justice, vol 35, no 1, pp 36-46, retrieved 1 April 2015 from http://journals.msvu.ca/index.php/atlantis/article/viewFile/171/ 178

Wright, S (2014) Knowledge that counts: Points systems and the governance of Danish universities, in Griffith, AI and Smith, DE, eds, Under New Public Management: Institutional ethnographies of changing front-line work, University of Toronto Press, Toronto, pp 294-337. 